\title{
27 Urban markets and agricultural transformation in Southern Africa
}

\author{
Thulasizwe Mkhabela
}

\section{Introduction}

Agriculture constitutes a significant part of the economies of all African countries; thus, as a sector it can contribute meaningfully towards the eradication of poverty and hunger, increasing intra-Africa trade and investments, accelerating industrialization, job creation and shared prosperity, among other continental priorities (NEPAD, 2013).

In the last 30 years, Africa's population has doubled overall and tripled in urban areas, and by 2030, more than half of Africa's population will reside in urban areas (Crush et al., 2011). Rapid urbanization, on the one hand, has created an "invisible crisis of urban food security" (Crush and Frayne, 2010). On the other hand, rapid urbanization has become one of the major driving forces for agricultural transformation, creating opportunities and demand for huge urban markets for food and other related agricultural product as demand for food increases due to more mouths to feed. Market demands for agricultural and food products, including staple crops (mainly maize for Southern Africa), have been historically one of the most important factors determining the choice of agricultural production systems and choice of enterprises by farmers in Southern Africa. International and national factors have historically dominated the process, but this has recently changed with regional factors such as internal migration, urbanization, a burgeoning middle class with stronger purchasing power and consequently increased demand for both staple and lifestyle foods assuming a greater role (Browder and Godfrey, 1997; Brondízio et al., 2002).

Against the foregoing background, it is imperative for both producers of agricultural products, including farmers, agribusinesses and policymakers, alike, to understand the marketing of agricultural and food products in urban areas. Urban markets for agricultural and food products are complex systems dogged by several challenges that require both understanding and proper governance. Improving the policies and processes for greater impact of urban markets should address the following tenets:

- Eliminating market failures, such as concentration and anti-competitive behaviours by dominant market players

- Absence of services such as credit facilities, insurance, etc. 
- The provision of public goods, such as transport infrastructure, bulk storage facilities, access to energy and water, information on prices, etc.

- Market regulations addressing distortions caused by international markets, price volatility and integration with global markets.

It is worth noting that while African agricultural production has increased over the years, it has not kept pace with population; thus, demand for food outstrips supply leading to the importation of substantive quantities of food products from international markets. Furthermore, it should be noted that the increase in African agricultural production has largely been due to increased area under planting rather than productivity growth. Most African countries' agriculture, including the Southern Africa region, is focused primarily on supplying national markets. However, the picture is beginning to change, with regional trade increasing owing to the proliferation of free trade areas that are reducing the cost of doing business among African countries.

Opportunities for the African agriculture sector abound. It is posited that the food market in Africa will triple by 2030, when it is expected to account for over US\$1 trillion compared with US\$313 billion in 2013 (Byerlee et al., 2013). In order to exploit these opportunities, the markets need to be functioning efficiently. Efficient agricultural markets enable cross-border trade in staple food and contribute to economic growth and food security. Better policies facilitate commodity exchanges (such as the South Africa Future Exchange [SAFEX] in Johannesburg), grain traders and agribusiness and international financial institutions to promote warehouse finance and expansion.

\section{Prevalent urban agricultural markets in Southern Africa}

The different agricultural commodities and products are generally marketed differently, largely dependent on their perishability or shelf life. Furthermore, there are nuanced differences between the different countries in terms of available marketing outlets for agricultural products. For commodities, such as maize - the staple crop - the price is formed internationally following the Chicago Board of Trade (CBOT) and other large future exchanges, including SAFEX. A commodity is defined as "an intermediate good with a standard quality, which can be traded on competitive and liquid global international markets" (Clark et al., 2001, p. 3). An important characteristic of commodities is the quality of the good which is verifiable ex ante, that is, information can be found easily before purchase. While commodities quality has been characterized by an increasing high degree of standardization, costs to acquire information about the product are generally low (Geman, 2005), which makes these goods suitable to trade.

In Southern Africa, SAFEX serves as the price setting mechanism for grains (maize, wheat) and oilseeds (soybeans, sunflower, etc.) where buyers and sellers trade their commodities. The futures exchange approach to marketing provides stability in terms of price in the sense that traders and buyers can enter into a contract at an agreed price and volumes prior to physical exchange of goods. 


\section{4}

Nowadays, the bulk of agricultural commodities are sold on forward contracts with limited quantities sold on the spot market, mainly by sellers who have storage facilities for hoarding their product to release at a later stage when supplies are low. Traders have storage facilities such as silos located strategically close to areas of production and transportation infrastructure to move the goods closer to urban markets where they are sold.

However, fresh produce and livestock are a different kettle of fish. Fresh produce markets are an integral, although diminishing, part of price formation, distribution and marketing of fresh produce in Southern Africa, particularly in South Africa. South Africa has about 18 National Fresh Produce Markets (NFPMs) owned by the municipalities of the cities in which they are located. There are also a number of smaller private fresh produce markets.

In South Africa, as would be expected, the four largest NFPMs are located in the four largest cities, namely, Johannesburg, Tshwane (Pretoria), Cape Town and Durban. These four NFPMs account for more than $74 \%$ of turnover and volumes traded through fresh produce markets. The Johannesburg Fresh Produce Market (also known as the Joburg Market) is the largest in the country in terms of volumes of fresh produce traded and income generated. The Joburg Market accounts for $47.7 \%$ of revenue generated in 2014-15, while Tshwane Market, being the second largest, accounted for $21.8 \%$ during the same period (Lekgau, 2016).

The foregoing discussion notwithstanding, the trend in fresh produce marketing is moving away from traditional wholesale marketing channels such as NFPMs towards supermarket chain stores and other direct marketing schemes, also known as alternative food networks (AFN), for example, farmers' markets. The importance of supermarkets has been discussed extensively in Chapters 2.5 and 4.3 in this book and also in the literature (for example, see Crush, 2019; Louw et al., 2008; D'Haese and Van Huylenbroeck, 2005; Reardon and Hopkins, 2006); thus, this chapter will only provide a synoptic discussion. Figure 27.1 presents a schematic illustration of the urban agri-food supply chain with supermarkets in the epicentre of it.

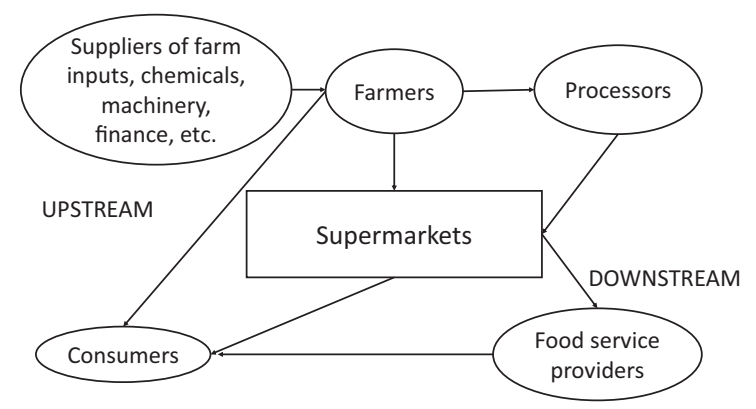

Figure 27.1 The urban agricultural food-supply chain

Source: Own representation 
It is now common knowledge that there has been a gradual transformation in agricultural urban agricultural markets marked, to a large extent, by a shift in the distribution of power in the agri-food supply chains away from manufacturers (processors) of branded food products to the global supermarkets chains (Burch and Lawrence, 2005; Burch and Lawrence, 2007). The Southern Africa market is largely dominated by a few large supermarkets of South African origin such as Pick 'n Pay, Shoprite \& Checkers, Spar (Dutch-owned but prominent in South Africa), Woolworths and Massmart (now part of the Walmart empire). However, there are a few local supermarkets that are making their presence felt in some Southern African countries. For example, Choppies, a Botswana supermarket, is growing in Botswana, Namibia, South Africa and Tanzania. Nakumatt, a Kenyan supermarket, is another one that is growing into the Southern Africa market.

Traditionally, supermarkets were just distribution channels for branded agrifood products from food manufacturers, but this has changed drastically with the shift in power in favour of supermarkets and supermarkets now have food brands of their own in their endeavours to be vertically integrated along the entire value chain. In the infant stages of advent of supermarkets own brands, popularly known as house brands, these brands were considered inferior to well-known brands owned by food manufacturers, but this perception has changed, with house brands now considered at par with established brands in the market and are often sold at lower prices than equivalent name-brand items (Greenblat, 2013; Wilkinson, 2002; Anderson and Narus, 1990). Furthermore, supermarkets are increasing engaging directly with farmers to source fresh produce bypassing the processors and shortening the value chain.

As African economies continue to develop and advance, it is expected that the dominance of supermarkets as markets for agri-food products in urban areas will also increase, as evidenced in the developed world (Wilkinson, 2002). Next the discussion turns to farmers' markets.

Farmers' markets are a growing trend in Africa, particularly in South Africa. Farmers' markets aim to bring producers and consumers together under direct marketing schemes, also known as alternative food networks for local and sustainable production and consumption of food (Figueroa-Rodriquez et al., 2019; Brown, 2001). The Australian Farmers' Market Association aptly defines a farmers' market as "a predominantly fresh food market that operates regularly within a community, at a focal public location that provides a suitable environment for farmers and food producers to sell farm-origin and associated value-added specialty foods products directly to consumers" (AFMA, 2014, p. 3). Farmers' markets are increasingly becoming commonplace in and around large cities and towns surrounded by farming communities in South Africa, and the phenomenon is spreading into neighbouring countries within the Southern African Development Community (SADC). The proliferation of farmers' markets is fuelled by several factors. Increasingly farmers are recognizing the value of farmers' markets as an alternative marketing channel. The advantages of farmers' markets to farmers include direct selling to consumers, thus cutting 


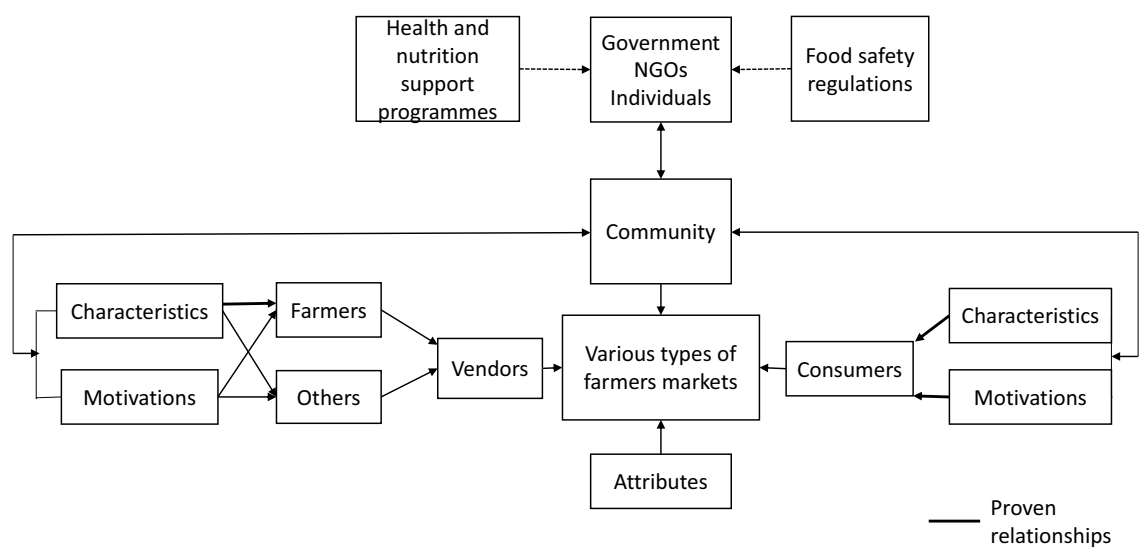

Figure 27.2 Partial framework for understanding farmers' markets

Source: Own representation

out the middleman and increasing revenue and also connecting with the consumers, thus better understanding the consumers' tastes and preferences. From the consumer's point of view, farmers' markets offer fresh food directly from the farm and satisfy the consumer's need to consume locally produced food with a lower carbon footprint. Furthermore, consumers perceive farmers' markets to a "special atmosphere", friendly, personal and smaller places compared to supermarkets (Sommer et al., 1981).

From available literature, it can be seen that the concept of farmers' markets is generally understood under three main aspects, namely the market and consumers, healthy eating promotion and food safety and environmental concerns (Kirwan, 2006; Fendrychová and Jehlička, 2018; Figueroa-Rodriquez et al., 2019). Figure 27.2 provides a partial framework for understanding farmers' markets based on the author's observations.

The important components of the system as depicted in Figure 27.2 represent the starting point: vendors, intrinsic attributes of the market, consumers, support organizations/institutions/individuals and the community, which relates to all the components at different levels.

\section{Policies, processes and strategies to improve and enhance urban markets}

There is general consensus that agriculture plays a pivotal role in economies of African countries, and marketing is an integral part of a well-functioning agricultural economy. Although agriculture is generally perceived as a rural activity, there is no denying that for the rural household "the landscape of daily life includes both rural and urban elements" (Douglass, 1998, p. 125). The ruralurban linkages are part and parcel of the local reality for household members 
carrying out the diverse tasks of generating income on and off-farm, maintaining a living space in the village and going to local and even distant towns and cities for shopping, marketing, work and specialized services. Thus, policies and strategies for enhancing urban agricultural markets should, a priori, also be aimed at linking rural and urban areas to overcome the urban- rural divide by incorporating the foregoing reality into development frameworks and, further, identify policy measures to foster mutual benefits for both town and country households.

At the top of the list of support services for creating an enabling environment for large and urban agricultural markets to thrive and be inclusive is the provision of quality infrastructure linking rural areas to urban areas. This infrastructure includes the construction and maintenance of good quality road network to facilitate an efficient movement of goods and services between the areas of production (often rural) and the marketplace, often in towns and cities. A good road network also reduces transportation costs and time spent travelling between two points, thus ensuring that agricultural goods reach their destination in good quality.

Farmers can take advantage of the rise of supermarkets by aggregating their produce, through secondary marketing cooperatives, to meet the quantities demanded by supermarkets. Supermarkets are reluctant to deal with individual smallholder farmers in sourcing their supplies as dealing with a plethora of suppliers and increases in transection costs, leading to greater variability in the quality of products. There is also the need to for farmers to be better organized in order to meet the regulations and standards in agri-food supply chains. Policymakers in African countries need to be cognizant of the stringent quantity and quality requirements of supermarkets, which often act as barriers to entry into formal and lucrative markets for most smallholder farmers and put in place policies and strategies to aggregate smallholder farmers produce.

Urban agriculture is another avenue that needs to be explored. Increased urban agricultural production, both in the cities and peri-urban areas would ensure sufficient throughput of marketable agricultural produce within shorter distances to large urban markets, thus enhancing their viability and efficiency.

Such policies and strategies aimed at enhancing urban agricultural markets would also invariably improve food security in urban areas through increasing the supply of food and reducing the price of food positively responding to improved availability, accessibility and affordability of food. The rural areas will continue to be the main source of agricultural and food products for the foreseeable future in African countries, including Southern Africa. This assertion is premised on the fact that there is still vast arable and agricultural land available in the rural areas, and considerable investments have been made in the form of infrastructure, such as irrigation and storage facilities.

\section{Conclusions}

Large agricultural markets, predominantly located in urban areas, will continue to play a pivotal role in the agricultural transformation process and 
economic development of African countries. The supply and demand of food will continue for as long as human beings exist, and properly functioning markets provide an ideal mechanism to allocate food and incentivize farmers and agribusinesses to continue producing food. It has been clearly demonstrated by numerous studies that urban markets are a major market outlet for agricultural products in Africa due to the high populations in urban areas and the proximity to export markets through better infrastructure. Large urban agricultural markets play an important function in generating income, employment creation and addressing food security challenges faced by many African urban areas.

It is posited in this chapter that urban agricultural markets will continue to grow and expand throughout the Southern Africa region and integration between neighbouring countries will grow as part of the reality presented by the process of agricultural transformation. Already, several agribusinesses and vendors from countries bordering South Africa, such as Eswatini (formerly known as Swaziland), Botswana and Lesotho source their fresh produce from South Africa, especially from the Joburg Market. A number of agro-processors, such as animal feed manufacturers, also procure their raw materials (Maize, soybeans, etc.) from SAFEX.

\section{References}

Anderson, J. and Narus, J. (1990) A model of distribution firms and manufacturer firm working partnerships. Journal of Marketing 54: 42-58.

Australian Farmers' Markets Association - AFMA. (2014) AFMA Strategic Plan 2014-2016. www.farmersmarkets.org.au/strategic-plan/. Accessed: June 24, 2019.

Brondízio, E.S., Safar, C.A.M. and Siqueira, A.D. (2002) The urban market for Ặֻ fruit (Euterpe oleracea Mart.) and rural land use change: ethnographic insights into the role of price and land tenure constraining agricultural choices in the Amazon estuary. Urban Ecosystems 6: 67-97.

Browder, J. and Godfrey, B. (1997) Rainforest Cities: Urbanization, Development and Globalization of the Brazilian Amazon. Columbia University Press, New York.

Brown, A. (2001) Counting farmers' markets. Geographical Review 91(4): 655-674.

Burch, D. and Lawrence, G. (2005) Supermarkets own brands, supply chains and the transformation of the agro-food system. Journal of Sociology of Agriculture and Food 13(1): 1-18.

Burch, D. and Lawrence, G. (2007) Supermarkets and Agri-food Supply Chains: Transformations in the Production and Consumption of Foods. Edward Elgar Publishing Ltd., Cheltenham, UK.

Byerlee, D., Garcia, A.F., Giertz, A. and Palmande, V. (2013) Growing Africa-Unlocking the Potential of Agribusiness. World Bank, Washington, DC.

Clark, E., Lesourd, J-B. and Thieblemont, R. (2001) International Commodity Trading: Physical and Derivative Markets Wiley Trading/Ephraim Clark, Jean-Baptiste Lesourd and Rene Thieblemont. Wiley, Chichester, New York.

Crush, J. (2019) The Growing Role of Supermarkets in Africa's Food Security. www.businesslive.co.za.

Crush, J. and Frayne, B. (2010) The Invisible Crisis: Urban Food Insecurity in Southern Africa. AFSUN Series No.1, Cape Town.

Crush, J., Hovorka, A. and Tevera, D. (2011) Food security in Southern African cities: The place of urban agriculture. Progress in Development Studies 11(4): 285-305. 
D'Haese, M. and Van Huylenbroeck, G. (2005) The rise of supermarkets and changing expenditure patterns of poor rural households: a case study of the Transkei area, South Africa. Food Policy 30(1): 97-113.

Douglass, M. (1998) A regional network strategy for reciprocal rural-urban linkages: An agenda for policy research with reference to Indonesia. Third World Planning Review 20(1): 124-154.

Fendrychová, L. and Jehlička, P. (2018). Revealing the hidden geography of alternative food networks: The travelling concept of farmers' markets. Geoforum 95: 1-10.

Figueroa-Rodriquez, K.A., Álvarez-Ávila, M del Carmen, Castillo, F.H., Rindermann, R.S. and Figueroa-Sandoval, B. (2019). Farmers' market actors, dynamics, and attributes: A bibliometric study. Sustainability 11(3): 745-760.

Geman, H. (2005) Commodity and Commodity Derivatives: Modelling and Pricing of Agriculturals, Metals, and Energy. John Wiley \& Sons, West Sussex.

Greenblat, E. (2013) Customers before suppliers, says Woolies boss. Sydney Morning Herald, 28 February. www.smh.com.au/business/retail/customers-before-suppliers-says-wooliesboss-20130228-2f7z0.html. Accessed: 17 May 2019.

Kirwan, J. (2006) The interpersonal world of direct marketing: Examining conventions of quality at UK farmers' markets. Journal of Rural Studies 22: 301-312.

Lekgau, S. (2016) Participation of Black Farmers in the Joburg Market. Presented at the 1st Subtropical Fruits Summit. Tzaneen, South Africa.

Louw, A., Jordaaon, D., Ndenga, L. and Kirsten, J.F. (2008) Alternative marketing options for small-scale farmers in the wake of changing agri-food supply chains in South Africa. Agrekon 47(3): 237-308.

New Economic Partnership for African Development - NEPAD. (2013) Comprehensive African Agriculture Development Programme (CAADP): Agriculture, Food Security and Nutrition. 2013 Report (CAADP Implementation Support). www.nepad.org. Accessed: June 24, 2019.

Reardon, T. and Hopkins, R. (2006) The supermarkets revolution in developing countries: Policies to address emerging tensions among supermarkets, suppliers and traditional retailers. European Journal of Development research 18(4): 522-545.

Sommer, R., Herrick, J. and Sommer, T. (1981). The behavioral ecology of supermarkets and farmers' markets. Journal of Environmental Psychology 1: 13-19.

Wilkinson, J. (2002) The final foods industry and the changing face of the global agro-food system. Sociologia Ruralis 42(4): 329-346. 